- комп'ютерна візуалізація навчальної інформації позитивно впливає на когнітивні процеси: стимулює увагу студентів під час виконання тестових завдань, активізує процеси мислення під час створення навчальних проектів екологічного спрямування. Застосування кольору, графіки, звука, сучасних засобів відеотехніки дозволяє моделювати різноманітні ситуації.

У подальших роботах розглянемо методику створення типологічних груп (за рівнем знань та спрямованістю інтересів), що дає змогу викладачам диференціювати самостійну роботу студентів, визначаючи коло питань для самостійного опрацювання.

\title{
Література
}

1. Бондаренко С. В. Моделювання складних системно-діяльнісних об'єктів у психолого-педагогічних дослідженнях [Електронний ресурс]/ С. В. Бондаренко.- Режим доступу: http : //roman.by/r-89699.html 2. Горячова М. В. Моделирование педагогических процессов [Электронный pecypc]/ M. В. Горячова. - Режим доступа: http: // www.rae.ru/zk/arj/2007/11/Goryachova.pdf. 3. Зязюн I. А. Краса педагогічної дії [навч. посіб.] / І. А. Зязюн, Г. М. Сагач. - Київ : Українсько-фінський інститут менеджменту i бізнесу, 1997. - 268 с. 4. Игнатова В. А. Педагогические аспекты синергетики / В. А. Игнатова // Педагогика. - 2001. - №8. - С. 26-31. 5. Кульневич С. В. Педагогика личности от концепций до технологий: [учеб.-практ. пособ. для учителей]/ С. В. Кульневич. - Ростов н/Д: Творческий центр «Учитель», 2001. - С. 106-109. 6. Маткин В. В. Ценностно-синергетический подход и его реализация в процессе педагогической подготовки будущих учителей / В. В. Маткин // Наука и школа. - 2001. № 6. - С. 10-12. 7. Нестеренко В. Г. Можливості особистості в контексті синергетичної моделі вищої освіти / В. Г. Нестеренко // Вища освіта України. - 2004. - № 1. - С. 25-34. 8. Новиков Д. А. Статистические методы в педагогических исследованиях (типовые случаи) / Д. А. Новиков. - Москва : МЗ-Пресс, 2004. - 67 с. 9. Хоружа Л. Л. У пошуках нової моделі педагогічної освіти / Л. Л. Хоружа // Вища школа. - 2009. - №11. - С. 23-31. 10. Чуб Е. В. Моделирование педагогического процесса как средство формирования ключевых компетенций будущего специалиста [Электронный ресурс] / Е. В. Чуб. - Режим доступа : http://www.conf.muh.ru/080215/thesis_Chub.htm 11. Штофф В. А. Моделирование и философия / В. А. Штофф. - Москва : Наука, 1966. - 300 с.

Аліна Бугра

\section{МОДЕЛЬ ІНДИВІДУАЛІЗАЦІЇ САМОСТІЙНОЇ НАВЧАЛЬНОЇ ДІЯЛЬНОСТІ СТУДЕНТІВ ТЕХНІЧНИХ СПЕЦІАЛЬНОСТЕЙ ВНЗ}

Бугра А. В. Модель індивідуалізації самостійної навчальної діяльності студентів технічних спеціальностей ВНЗ.

У статті обгрунтовано необхідність розв'язання проблеми індивідуалізації самостійної навчальної діяльності студентів технічних спеціальностей під час вивчення математики у вищому навчальному закладі. Автором запропоновано експериментальну модель індивідуалізації, яка містить цільовий, теоретико-методологічний, змістовий, технологічний, оцінно-результативний блоки. Методологічним підгрунтям побудови моделі визначено системний, синергетичний, особистісно зорієнтований, діяльнісний, варіативно-модельний i компетентнісний підходи.

Ключові слова: модель, моделювання, педагогічне моделювання, структура моделі, 
індивідуалізація, самостійна навчальна діяльність.

Бугра А. В. Модель индивидуализации самостоятельной учебной деятельности студентов технических специальностей вузов.

В статье обоснована необходимость решения проблемы индивидуализации самостоятельной учебной деятельности студентов технических специальностей при изучении математики в высшем учебном заведении. Автором предложена экспериментальная модель индивидуализации, которая содержит целевой, теоретико-методологический, содержательный, технологический, оценочно-результативный блоки. Методологическим основанием построения модели определены системный, синергетический, личностно ориентированный, деятельностный, вариативно-модельный и компетентностный подходы.

Ключевые слова: модель, моделирование, педагогическое моделирование, структура модели, индивидуализация, самостоятельная учебная деятельность.

Bugra A. V. Self-learning activity individualization model of students of engineering specialities at HEI.

In the article the necessity of solving the problem of individualization of independent educational activity of students of technical specialties in the study of mathematics at high school is gruonded. The author has offered the experimental model of individualization containing the target, theoretical and methodological, informative, technological, evaluative-efficient units. System, synergetic, learner-centered, activity, variative and simulation, and competency-based approaches have been defined as the methodological basis for a model development.

Key words: model, modeling, pedagogical modeling, model structure, individualization, self-learning activities.

Проблема підготовки випускника вищої технічної школи до самоосвіти протягом життя набула особливої актуальності в сучасних умовах бурхливого розвитку науки і техніки, оскільки для творчої життєдіяльності особистості необхідним є постійне оновлення професійних знань та вмінь. У зв'язку з цим активізувалися науково-педагогічні пошуки, вектором яких є удосконалення системи самостійної навчальної діяльності студентів вищої школи (В. Антропов, В. Буряк, О. Малихін, О. Коновал та ін.), зокрема, студентів технічних спеціальностей (О. Королюк, Ю. Зіньковський, Т. Горюнова). Проте, незважаючи на розлогі наукові розвідки в цьому дослідницькому полі, окремі аспекти організації самостійної навчальної діяльності студентів ВНЗ не були досліджені грунтовно. Першочергово це стосується проблеми індивідуалізації самостійної навчальної діяльності (CHД) студентів при вивченні математики. Саме тому наші дослідницькі зусилля були спрямовані на теоретичне розроблення та апробацію моделі індивідуалізації СНД студентів технічних спеціальностей BH3 з урахуванням специфіки навчання математики. Висвітлення окремих результатів наших дослідницьких пошуків у цьому напрямі ми визначили метою пропонованої cmammi.

За визначенням Б. Совєтова та С. Яковлєва: «Модель (лат. modulus - міра) - це об'єктзаступник об'єкта оригіналу, що забезпечує вивчення деяких властивостей оригіналу» [2, с. 65].

Звертаючись до методу моделювання, важливо врахувати результати дидактичних розвідок М. Кларіна, який здійснив характеристику моделей організації навчального процесу. На переконання автора, поняття моделі навчання грунтується на такому: модель описує навчальний процес цілісно, враховуючи не тільки логіко-змістову сторону навчання, але й 
послідовність у часі, що особливо важливо для цілісного уявлення про загальну картину цього процесу [4]. Окрім того, «метод моделювання як спосіб пізнання дійсності, надає можливості логічно побудувати послідовні дії, на основі обгрунтованих положень створити конструкцію, що відображає сутність системи чи процесу i механізми їхнього функціонування, розкрити динаміку взаємозв'язку складників, виявити шляхи оптимізуючого впливу на процес функціонування певного явища» [Тамо ж, с. 45].

Процес моделювання - це відтворення характеристик одного об'єкта на іншому, що обумовлюється раніше визначеною метою та спрямовується на практичне застосування результатів. Окрім того, моделювання є ще й методом створення і дослідження моделей, при цьому наукова модель розглядається як уявна чи матеріальна реалізована система, що адекватно відображає предмет дослідження і здатна змінити його так, що вивчення моделі сприяє отриманню нової інформації про цей предмет [3, с. 63]. Результатом моделювання $€$ модель, яка використовується для визначення або уточнення характеристик і раціоналізації способів побудови сконструйованих об'єктів.

Доречним слід уважати зауваження А. Чижа щодо педагогічної моделі як створеної або обраної дослідником системи, що припускає експериментальну перевірку [10].

Педагогічне моделювання, за визначенням Є. Лопатко, дослідження педагогічних об'єктів (явищ) за допомогою моделювання понятійних, процесуальних, структурнозмістових i концептуальних характеристик та окремих «сторін» навчально-виховного процесу в межах певного визначеного соціокультурного простору на загальноосвітньому, професійно-орієнтованому або іншому рівнях [6].

Ураховуючи дослідницьку позицію Ю. Бабанського щодо оптимізації навчальновиховного процесу [2] та узагальнюючи вищевикладене, можна виокремити особливості педагогічного моделювання, які постали підгрунтям побудови експериментальної моделі процесу індивідуалізації СНД студентів технічних спеціальностей ВНЗ під час вивчення математичних дисциплін.

1. Модель у педагогіці розглядається як створена або обрана дослідником система, яка відтворює для цілі пізнання характеристики (компоненти, елементи, властивості, відношення, параметри і т. п.) об'єкта, що вивчається, і внаслідок цього знаходиться з ним у такому відношенні заміщення й схожості, що iï дослідження слугує опосередкованим способом отримання знання про цей об'єкт і дає інформацію, яка однозначно перетворюється в інформацію про пізнаваний об'єкт і припускає експериментальну перевірку.

2. Педагогічне моделювання має евристичний характер, указує на те, що побудова i вивчення моделей переслідують мету отримання нової інформації про педагогічні об'єкти, явища та процеси, які $\epsilon$ предметом моделювання, можливі шляхи їх практичного використання. Системний підхід і метод моделювання складних педагогічних процесів, таких як індивідуалізація самостійної навчальної діяльності, дають можливість їх багатобічного i цілісного дослідження.

3. На основі використання аналогій, які мають не лише пояснювальну, але й прогностичну та практичну значущість, моделювання допомагає зробити вивчення педагогічних явищ та процесів більш глибоким за своєю суттю.

4. Педагогічне моделювання допомагає наочно (у вигляді схем, малюнків, опису, коротких словесних характеристик) схарактеризувати процес, який вивчається, визначити поетапну логіку його розгортання та (або) технологію реалізації моделі.

У процесі моделювання ми насамперед урахували, що теперішнього часу в освіті відбувається перехід від авторитарної моделі навчального процесу до особистісно 
зорієнтованої моделі, в центрі якої перебуває студент з його потребами, мотивами, знаннями, ціннісними настановами [8, с. 43].

Теоретичний аналіз досліджень, присвячених вивченню педагогічних систем, показав, що мають місце різні точки зору на структуру педагогічної моделі. Нашій дослідницькій позиції найбільш близькою $є$ та, в якій у структурі моделі використовують цільовий, змістовий, організаційно-діяльнісний (процесуальний) та результативний компоненти [8, с. 48].

Використовуючи метод моделювання в нашому дослідженні, ми розглядаємо експериментальну модель індивідуалізації самостійної навчальної діяльності студентів технічних спеціальностей ВНЗ у процесі вивчення математичних дисциплін як послідовну, складну систему взаємопов'язаних компонентів (блоків), яка грунтується на вимогах урахування і розвитку індивідуально-типологічних особливостей студентів, необхідності задоволення суспільних потреб у фахово компетентних фахівцях 3 вищою технічною освітою, готових до постійної самоосвіти («освіти протягом життя»). При цьому ми не претендуємо на остаточне розв'язання проблеми індивідуалізації самостійної навчальної діяльності в процесі математичної підготовки, а пропонуємо один із варіантів її розв'язання, представлений у вигляді експериментальної моделі (схема).

Компонентами (блоками) «Моделі індивідуалізації самостійної навчальної діяльності студентів ВНЗ у процесі вивчення математичних дисциплін» ми визначили: цільовий, теоретико-методологічний, змістовий, технологічний (що у свою чергу містить діагностувальний та процесуальний складники) і оцінно-результативний.

Характеризуючи сутність основних блоків експериментальної моделі, зазначимо, що відповідно до потреб суспільства, конкретизованих у Законі «Про вищу освіту», від студента вищої технічної школи вимагають формування професійної компетентності фахівця (майбутнього інженера), з притаманними йому такими якостями як здатність самостійно приймати відповідні рішення, усвідомлювати і самостійно визначати мету професійної діяльності, складником якої $є$ постійна навчально-пізнавальна діяльність, оцінювати й коригувати іiі процес та результати з урахуванням тенденцій науково-технічного прогресу. На основі цього соціальне замовлення в контексті нашого дослідження можна окреслити як формування особистості фахівця з вищою технічною освітою, підготовленого до самостійної навчальної діяльності на рівні, який задовольняє вимоги вищої професійної школи i суспільства в цілому.

Цільовий блок ураховує особливості соціального замовлення та визначає мету індивідуалізації самостійної навчальної діяльності студентів під час вивчення математичних дисциплін.

Відповідно до соціального замовлення загальна изільова спрямованість експериментальної моделі пов'язана 3 підвищенням рівня готовності студентів ВНЗ до самостійної навчальної діяльності у процесі математичної підготовки на засадах урахування та розвитку їх індивідуально-типологічних особливостей.

Теоретико-методологічний блок характеризує систему методологічних підходів та принципів індивідуалізації СНД, обгрунтовує необхідність побудови експериментальної моделі 3 урахуванням системи вихідних, найголовніших теоретичних положень, які характеризують загальні підходи до організації навчально-виховного процесу підготовки спеціаліста [6, с. 49]. Система методологічних підходів містить: системний, синергетичний, особистісно зорієнтований, діяльнісний, варіативно-модельний і комплексний підходи. 


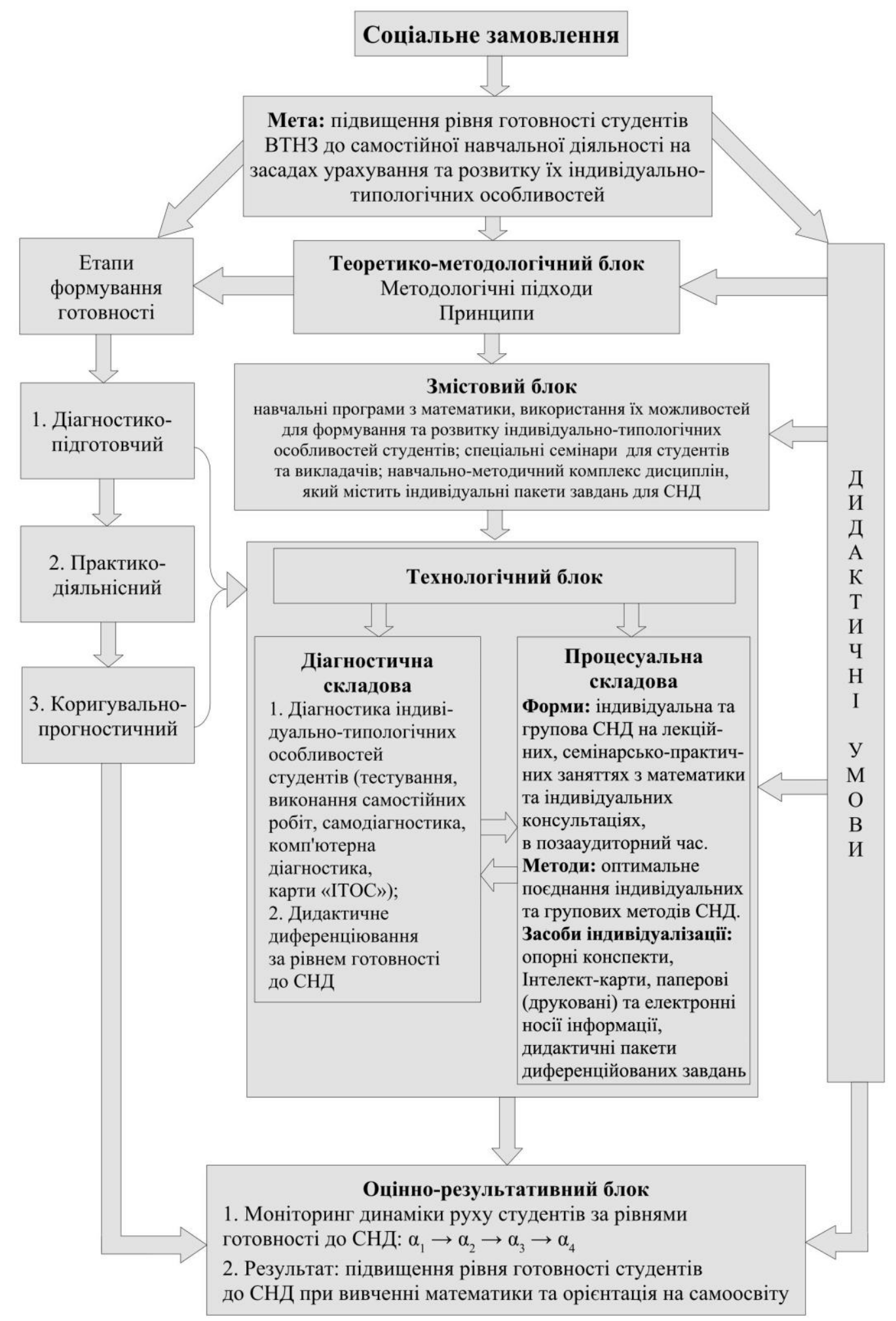

Схема. Модель індивідуалізації самостійної навчальної навчальної діяльності студентів технічних спеціальностей ВНЗ при вивченні математичних дисциплін

Змістовий окреслює специфіку змісту математичної підготовки і визначає іï можливості в засвоєнні студентами теоретичних та практичних засад самостійної навчальної діяльності 3 урахуванням їх особистісних потреб та індивідуально-типологічних особливостей.

Технологічний блок передбачає добір форм, методів, засобів діагностики індивідуально-типологічних особливостей студентів, їх дидактичне диференціювання, на 
засадах якого має здійснюватися індивідуальна та групова СНД на лекційних, семінарськопрактичних заняттях, консультаціях і в позааудиторний час.

Завершальною фазою реалізації моделі постає оцінно-результативний блок. Його призначення - забезпечення системного моніторингу процесу та результатів самостійної навчальної діяльності студентів у процесі математичної підготовки, визначення динаміки руху студентів у типологічних групах у напрямі зростання рівнів готовності до СНД $\left(\alpha_{1} \rightarrow \alpha_{2} \rightarrow \alpha_{3} \rightarrow \alpha_{4}\right)$. Результатом ефективності «моделі» ми визначаємо підвищення цього рівня до оптимально можливого відповідно до індивідуально-типологічних особливостей кожного студента та орієнтації особистості на постійну самоосвіту.

Отже, ми надали загальну характеристику розробленої в процесі дослідноекспериментальної роботи моделі індивідуалізації самостійної навчальної діяльності студентів технічних спеціальностей ВНЗ під час вивчення математичних дисциплін. Структура експериментальної моделі містить: соціальне замовлення, яке детермінує взаємозумовлені та взаємопов'язані між собою: цільовий, теоретико-методологічний, змістовий, технологічний, та оцінно-результативний компоненти (блоки). Для забезпечення функціонування експериментальної моделі в реальній навчальній практиці необхідно обгрунтувати дидактичні умови ефективності цього процесу. При цьому слід зауважити, що визначення умов дієвості експериментальної моделі постає не менш важливим ніж конструювання, адже одне й те ж педагогічне явище, яке реалізується в різних умовах може привести до отримання різних результатів. Обгрунтування умов реалізації моделі індивідуалізації СНД студентів технічних спеціальностей ВНЗ під час вивчення математичних дисциплін ми вбачаємо перспективними напрямом подальших наукових розвідок.

\section{Література}

1. Антропов В. А. Организация самостоятельной работы студентов / В. А. Антропов, Н. И. Шаталова. - Екатеринбург : Изд-во Урал. гос. ун-т путей сообщения, 2000. - 76 с. 2. Бабанский Ю. К. Проблемы повышения эффективности педагогических исследований / Ю. К. Бабанский. - Москва : Педагогика, 1982. - 192 с. З. Кабак В. Модель підготовки майбутніх інженерів-педагогів технічного університету до професійної діяльності засобами комп’ютерних технологій / Віталій Кабак. - Нова педагогічна думка : Науково-методичний журнал. - 2013. - № 3 (75). - С. 63-66. 4. Кларин М. В. Инновационная модель обучения в зарубежных педагогических поисках / М. В. Кларин. - Москва : Педагогика, 1994. - 167 с. 5. Лопатко Є. О. Моделювання педагогічних систем i процесів / Є. О. Лопатко.Слов'янськ : СДПУ, 2010. - 148 с. 6. Матвіснко О. В. Створення моделі спеціаліста на засадах теорії освітньої інноватики / О.В. Матвієнко // Педагогіка і психологія. - 2004. - № 3 (44). - С. 44-52. 7. Слюсаренко Н. В. Дистанційна форма навчання у фаховій підготовці майбутніх економістів : [навч.-метод. посіб.] / Н. В. Слюсаренко, О.В.Кохановська. Херсон : КВНЗ «Херсонська академія неперервної освіти», 2012. - 104 с. 8. Советов Б. Я. Моделирование систем : [учеб. для вузов] / Б. Я. Советов, С. А. Яковлев. - [3-е изд., перераб. и доп.]. - Москва : Высш. школа, 2001. - 343 с. 9. Философский энциклопедический словарь / [ред. Аверинцев С. С.]. - [2-е изд.]. - Москва : Сов. энциклопедия, 1989. - 815 с. 10. Чиж А. Н. История вопроса разработки модели учителя в 60-80-е годы XX столетия/ А. Н. Чиж // Ціннісні пріоритети освіти у XXI столітті : Орієнтири та напрямки сучасної освіти : Матеріали II Міжнародної наук.-практ. конф./ редкол. В. С. Курило та ін.; М-во освіти і науки України, Луганський нац. пед. ун-т імені Тараса Шевченка. - Луганськ. 2005. -Ч. 4. - C. 261-269. 